\title{
Expression of Concern to: Changing climate and its impacts on Assam, Northeast India
}

Debojyoti Das*

${ }^{*}$ Correspondence: ukdebodas@gmail.com Department of History, Classics and Archaeology, Birkbeck College, Universty of London, 27 Russel Square, London WC1H OXG, UK

\section{Expression of Concern to: Bandung J of Global South (2015) 2:26 https://doi.org/10.1186/s40728-015-0028-4}

The Editor-in-Chief is issuing an editorial expression of concern to alert readers that an allegation of plagiarism has been brought with respect to this article (Das 2016). We have submitted the allegation to the institution where the author was affiliated when the article was written and requested an investigation. The author does not agree with this notice.

The original article can be found online at https://doi.org/10.1186/s40728-015-0028-4.

\section{Publisher's Note}

Springer Nature remains neutral with regard to jurisdictional claims in published maps and institutional affiliations.

Received: 22 January 2018 Accepted: 22 January 2018

Published online: 08 February 2018

Reference

Das, D. 2016. Changing climate and its impacts on Assam, Northeast India. Bandung J of Global South 2: 26. https://doi. org/10.1186/s40728-015-0028-4. 